\title{
Saying "story" in the newsroom. Towards a linguistic ethnography of narrative lexicon in broadcast news
}

\author{
Gilles Merminod, University of Lausanne, Faculty of Arts, Centre of Linguistics and \\ Language Sciences \\ gilles.merminod@unil.ch
}

\begin{abstract}
Despite a general agreement on the narrative nature of news, the question of what it means for the journalists to tell a story is usually taken for granted, while the analysis of the actual narrative practices in the newsrooms often remains shallow. A way of overcoming this state of affairs is to have a look at the narrative practices and norms in the newsroom. On the one hand, one can track the sites of narrative engagement in the newsroom, where journalists are telling or handling stories in order to achieve their work of making news. On the other hand, one can track the metacommentaries that foreground a narrative orientation to news, when journalists evaluate storying choices or when they use a narrative-related lexicon. This paper explores the latter aspect by tracking the uses of the word "histoire " (story) in the newsroom of a Swiss Public Broadcasting Corporation. The paper identifies and analyses three different meanings of " histoire": " histoire" as a genre, "histoire" as a set of information and "histoire" as a semiotic product. As a reflexive means, "histoire" enables the media practitioners to navigate the very practical tasks entailed by the production of the multimodal artefact that a television news item is.
\end{abstract}

\section{Keywords}

News, narrative, story, histoire, metalanguage, formulations, newsroom, small story research, linguistic ethnography

\section{News, stories and narrative}

In communication and media studies as much as in journalism education, news and stories appear to be interchangeable notions. One can explain this partly because news and stories are both the result of verbal practices dealing with "what happens," in terms of current or past events. The similarity of both news and stories has led scholars of diverse disciplines - such as linguistics, communication and sociology - to use the narrative conceptual apparatus to study news. However, despite a general agreement about the narrative nature of news, the question of what it means for the journalists to tell a story is usually taken for granted, while the analysis of the actual newsroom practices related to narration often remains shallow.

Another motivation for a narrative approach to news lies in the use of the word "story" in the newsrooms (Tuchman, 1976;
Bell, 1991), which would suggest the journalists' narrative orientation to the world.

\section{The journalist's work is focused on the get- ting and writing of stories. This is reflected in the snatches of phrases in which newsroom business is conducted. A good journalist "gets good stories" or "knows a good story." A crit- ical news editor asks: "Is this really a story?" "Where's the story in this?" (Bell, 1991, p. 147)}

Nevertheless, in such cases, the meaning of "story" is taken for granted, without questioning what the journalists are doing when they are saying this word or what it really means in its context of use. Additionally, if "story" seems to be used in newsrooms that are English-speaking, one might very well wonder whether or not the German word Geschichte, the French word histoire or the Italian word storia are in use in the journalists' daily routines and, if so, to what extent. 
To address such concerns, this paper is divided into three parts. First of all, it sketches some of the main issues raised by the study of narrative and offers a brief overview of the current narrative approaches to news. Then, it examines how the word "histoire» (story in French) is used by a journalist during the production of a single broadcast news item. Finally, it discusses and indicates some aspects that deserve further investigation.

\subsection{Narrative and narrative approaches}

Narrative is a fickle notion "that resists straightforward and agreed-upon definitions and conceptualizations" (De Fina \& Georgakopoulou, 2012, p. 1). Depending on research traditions ranging from narratology and folklore studies to linguistics, philosophy, psychology, sociology, anthropology and even medicine (Mishler, 1995; Fludernik, 2005; Hyvärinen, 2006; Herman, 2009; De Fina \& Georgakopoulou, 2012), a narrative can be considered as a semiotic product (a text, a multimodal artefact), a mental construct (a mode, a cognitive schema, a way of making sense and apprehending reality) or a communicative practice (a social process, a resource for interaction). Because of this, a full-fledged ${ }^{1}$ or prototypical narrative has been diversely defined as "one method of recapitulating past experience by matching a verbal sequence of clauses to the sequence of events which actually occurred" (Labov \& Waletzky, 1967, p. 95), "a mediation between man and the world, between man and man, between man and himself" (Ricœur, 1991, p. 26-27) as well as "a representation [...] about a structured time-course of particularized events [...] such that they introduce some sort of disruption or disequilibrium into a storyworld involving human or human-like agents [...] affected by the occurrences at issue" (Herman, 2009, p. XII). Whether it is as a mode of communication or a mode of representation, a narrative deals with time and space, events and actions,

1 But see the point made by Georgakopoulou (2007) about the ideologies surrounding the idea of proper narrative. human agency and experience, continuity and change.

Narrative studies have generally focused on the universal features of stories rather than on the culturally bound ones (De Fina \& Georgakopoulou, 2012). According to Herman (2009), narrative studies have underlined three diverse but related aspects of stories: events sequencing, world depiction and rendering of experience $^{2}$. One can consider the case of a story about people surviving a plane crash in Indonesia to illustrate this three-way split. The studies interested in the ordering of events would examine, for instance, whether the narrative follows the timeline (by representing the crash and then the people fleeing) or not (by mentioning the results before the cause). The studies focusing on world-making could study if the narrative depicts solely the immediate context of the crash (for instance, the plane burning) or if it locates the event in a master narrative (about recurrent crashes in Indonesia, for instance). The studies focusing on the depiction of experience could examine if the narrative represents the singular experience of a passenger fleeing or that of a collective.

Apart from key issues, narrative studies have provided a series of theoretical notions (see Herman, 2007; Hühn et al., 2014). These notions relate to text organisation (e.g. story/discourse; kernel/ satellites; orientation, complication, resolution), grammar of events (e.g. cause, consequence; plot, closure; transformation; character, settings) and logic of actions (e.g. agent, motive, intention, goal,

2 Another way of summarizing narrative studies' key issues is suggested by Luginbühl, Schwab \& Burger (2004) building on the work of Genette (1998): "Zentrale Fragen der Narrationstheorie sind die nach den Instanzen, die über ein Ereignis berichten, also nach den Erzählern; nach den Figuren, die in einer Erzählung vorkommen und zu Wort kommen oder nicht; nach der zeitlichen Ordnung der Erzählung, nach den Perspektiven, aus welchen das Geschehen erzählt wird; nach dem Modus der Erzählung (Distanz der Erzählung zur Geschichte, Blickwinkel auf die Geschichte)» (Luginbühl, Schwab \& Burger 2004, p. 17-18). 
means) but also to communication (e.g. narrator/narratee; fact/fiction; focalization; evaluation; configuration) and genre theories (e.g. myth, tale, novel, anecdote, joke). The narrative descriptive apparatus has been used to study news, especially hard news - the newsworkers' "staple product" (Bell, 1991, p. 14) - and, as accurately underlined by Montgomery (2007), mainly written news. Nevertheless, if some studies have been explicitly based on narrative theories (e.g. Bell, 1991; Luginbühl, Schwab \& Burger, 2004), others have only loosely referred to them or have drawn on our common understanding of what a story is (e.g. Tuchman, 1976; Schudson, 1982).

\subsection{Narrative approaches to news}

Apart from perspectives that have considered narrative journalism as a specific genre emphasizing literary aesthetics, creativity and authorhood (see Dardenne, 2005; Tenenboim-Weinblatt, 2009; Vanoost, 2013), narrative approaches to news have mainly addressed two issues: the textualisation of news items relating to narrative structures and the identification of news events relating to narrative frames.

Regarding the textualisation of news, studies have focused either on the analysis of isolated texts or on the analysis of chains of texts. The studies analysing isolated texts or groups of texts isolated from each other have described how news items are organized regarding the event they cover (Barthes, 1964; Van Dijk, 1983, 1985, 1986, 1988a, 1988b; Bell, 1991, 1994, 1998; Jamet \& Jannet, 1999; Ungerer, 2001; Montgomery, 2005, 2007; Adam, 2011). Drawing mainly on structural linguistics, psycholinguistics and sociolinguistics, these approaches have generally distinguished news stories from "personal/faceto-face/everyday" stories, and have tended to compare the former with the latter, as illustrated by Allan Bell's studies making use of the work of Labov on oral narratives of personal experience:

In news, the abstract is obligatory not optional. Orientating and evaluative material occurs in a similar fashion to personal narratives, but tends to concentrate in the first sentence. The central action of the news story is told in non-chronological order, with result presented first followed by a complex recycling through various time zones down through the story. (Bell, 1994, p. 107)

As for the studies examining the chains of texts, they have described the narrative dynamics that arise from text to text when covering developing or iterative events (Baroni, Revaz \& Pahud, 2006; Revaz \& Baroni, 2007; Revaz, Pahud \& Baroni, 2007, 2008, 2009; Baroni, 2016; Revaz, 2009a, 2009b). More precisely, these approaches have been twofold: on the one hand, they have focused on how textual chains are sensitive to the development of events; on the other hand, they have worked on how the upstream and downstream of events are depicted in single texts.

The studies concerning the identification of news events can also be divided into two trends. On the one hand, some studies have analysed how stories frame news events (Tuchman, 1976, 1978; Bird \& Dardennes, 1988, 2009; Lule, 2001). On the other hand, there are studies that have looked at how news participates in the creation of an "abstract text" about particular events and enables the strengthening or the countering of shared master narratives (Mouillaud \& Tétu, 1989; Tétu, 2000; Dubied, 2004; Arquenbourg, 2005; Lits, 2008). Both trends have drawn on diverse notions, such as frame (Goffman, 1974), typification (Schütz, 1953), myth (Malinowski, 1926; Barthes, 1957; Eliade, 1963; Lévi-Strauss, 1964, 1967, 1968, 1971) and configuration (Ricœur, 1983, 1984, 1985). Originating from various traditions, such notions have been used to grasp what underpins the narrative organisation of the interpretation of events in terms of causality and consequence, agents and circumstances, motives and intentions, purposes and responsibilities, values and ideologies. Most of these notions favour an atemporal vision of narrative, understood as a network of relations between different parameters (cause, consequence, agent, etc.), similar to the Greimasian actantial model (Greimas, 1966) that suggests a log- 
ic of narrative action relating to a network of relationships between actantial functions. The Ricœurian notion of configuration nevertheless entails a temporal feature that takes into account the changing nature of events, the idea that a narrative is oriented toward its end, its closure.

Both the textualisation and identification approaches have underlined some crucial aspects of news, such as a preference for a textualisation of events that presents consequences first (emphasizing the role of a particular part of news texts, the lead) and the pervasiveness of prototypical storylines. However, as illuminating as they are, these approaches have some limitations when the matter at issue is to know whether or not journalists are telling stories. Firstly, these approaches have mainly focused on events rather than on the rendering of experience or on world-making. Secondly, these approaches have mainly studied the final product and do not enable us to apprehend the narrative practices that participate in the process of news production. Thirdly, if newsroom ethnography has shed light on what happens backstage, the lack of linguistic and fine-grained interactional analysis prevents us from understanding precisely how, when and why news events are or are not identified relating to narrative frames as well as when, how and why news items are or are not designed as narrative structures.

A way of overcoming these limitations is to have a look at the narrative practices and norms in the newsroom. To do so, we have two loci of study. On the one hand, we can track the sites of narrative engagement in the newsroom, places where journalists move into narrative activities, where they are telling or handling stories in order to achieve their work of making news (Perrin, 2013; Merminod \& Burger, forthcoming). On the other hand, we can track the metacommentaries that foreground a narrative orientation to news, when journalists evaluate storying choices (Perrin, 2011; Merminod, 2016) or when they use a narrative-related lexicon. The paper aims to explore this latter aspect by tracking the use of the word «histoire» (story) in a newsroom.

\subsection{Data and methods}

\subsubsection{Data}

To examine the use of the word "histoire» by media practitioners, the paper draws on a data set collected in the newsrooms of the Swiss Public Broadcasting Corporation in 2007 within the Research Project Idée Suisse $^{3}$. The data set gathers interviews with journalists, computer logs of their daily writing activities and audio-visual recordings of news production processes, such as editorial conferences, writing sessions and cutting-room activities. During their fieldwork, Perrin and colleagues followed several journalists, each one during one week, day-to-day, from the morning to the evening.

The paper focuses on the case of a Swiss-French television's journalist (CA), who was followed from Monday March 5 to Friday March 9. More precisely, it focuses on two events: a preliminary interview with CA on Monday and a session of collaborative work on Wednesday involving CA and a cutter. In the preliminary interview, which lasts 45 minutes, the journalist shares his professional credo with a researcher. The session of collaborative work recorded on Wednesday documents the way the journalist and the cutter are co-producing a news item about a plane crash. The recording lasts approximately 1 hour 45 minutes.

These 2 hours and 30 minutes of recording see 9 instances of the word «histoire», which were uttered by the journalist but not by the researcher or the cutter. It is worth mentioning that, during the three morning editorial meetings (8:30, 9:15 and $9: 30$ ) that preceded the co-production of the plane crash news item, the word «his-

3 Funded by the Swiss National Science Foundation, the research project Idée suisse: Sprachpolitik, Sprachnorm und Sprachpraxis am Beispiel der SRG SSR (2005-2007) was part of a National Research Program, Language Diversity and Linguistic Competence in Switzerland (NRP 56). See Perrin et al. (2008) for a summary. 
toire» was not uttered, at least not in relation to this particular news item.

\subsubsection{Methods}

The paper adopts the vantage point of Linguistic Ethnography (Rampton, Maybin \& Roberts, 2015) and, more precisely, that of a linguistic ethnographic approach to news production (e.g. Van Hout \& Jacobs, 2008; Cotter, 2010; News Text \& Talk Research Group, 2011; Perrin, 2013; Van Hout, 2015; Jacobs, 2017; Burger 2018). It combines the insights of an ethnographic knowledge of what happens in a newsroom with a fine-grained linguistic analysis of actual news-making processes and news products.

Drawing on the work of Stokoe and Edwards (2006) on story formulations, the paper tracks the instances of the word «histoire» with a keen interest in "the sequential organization of such formulations - their occasioning, action-orientation and uptake -" (Stokoe \& Edwards, 2006 , p. 58) as well as "their action-orientation and the way they are shaped for the occasions of their production" (Stokoe \& Edwards, 2006, p. 56). Nevertheless, as claimed by Deppermann, "[e]thnographic background is needed to discover how interactional histories are reflected by the choice of a formulation, [...] how institutional agendas and professional knowledge are indexed by formulations" (Depperman, 2011, p. 120). The analysis of story formulations is thus led by two questions: "why that now?" (Schegloff \& Sacks, 1973) and "what is it that's going on here?" (Goffman, 1974; also Scollon, 1998). The former helps us to take into account the sequential emergence of the word «histoire", the latter enables us to grasp the social practices that converge during its moment of emergence.

Because we assume that "metalanguage can work at an ideological level, and influence people's actions and priorities in a wide range of ways" (Jaworski, Coupland \& Galasinski, 2004, p. 3), our examination of story formulations is not only carried out to study the situated functions of these formulations in the newsroom but also to apprehend their social meanings.
By doing so, the paper's reflection is more broadly anchored in the Small Stories Research, which aims, among other things, to "document local theories of what constitutes a narrative and what the role of narrative is in [a] specific communit[y]" (Georgakopoulou, 2007, p. 21), by "ar$\mathrm{gu}$ [ing] for the inclusion of emic criteria in definitions of narrative as complementing and even overriding etic criteria" (Georgakopoulou, 2015, p. 260).

\section{Saying " histoire " in a television newsroom}

The case study is divided into two parts. Firstly, it analyses the journalist's usage of «histoire» to reflect on broadcast news production during the preliminary interview. Secondly, it examines the journalist's usage of «histoire» to produce a broadcast news item in the physical space of a cutting-room.

\subsection{Saying «histoire» to reflect on broadcast news production}

The first excerpt comes from the preliminary interview between journalist CA and the researcher. Prompted by the researcher to talk about the goals of a TV news bulletin, CA mentions the risks of drifts relating to the editorial choices. The researcher asks him to follow up on this (l.1). First, the journalist talks about the non-coverage of iterative bad news, such as never-ending armed conflicts ${ }^{4}$. Then, he describes another type of drift: favouring good news at the end of the news bulletin (1.2-7).

In the excerpt, the journalist first suggests a characterisation of good news (1.4-7), and then gives an example of good news (1.8-14). "Histoire» appears twice (1.5 and 1.6) in a chain of reformulations, ending with a relative clause that specifies the function of such stories (1.6: "which are appealing"). In both cases, "histoire» is associated with derogatory qualifiers (the adjectives petit and croquingnolesque, the suffix -ette) as well as realized by a plural indefinite article (des) that enables a

4 This is not transcribed in excerpt 1. 


\section{Excerpt 1: “Good news, [...] charming anecdotes, even nice stories" $(\text { March 5, 2007) })^{\mathrm{a}}$}

\begin{tabular}{|c|c|}
\hline $1 \mathrm{R}$ & $\begin{array}{l}\text { Tu peux donner un exemple? [...] Ce serait quoi une } \\
\text { dérive? } \\
\text { Can you give me an example? [...] What is a drift? } \\
{[\ldots]}\end{array}$ \\
\hline $2 \mathrm{~J}$ & $\begin{array}{l}\text { Une dérive possible aussi, je dirais, c'est: } \\
\text { A potential drift also, I would say, this is: }\end{array}$ \\
\hline 3 & $\begin{array}{l}\text { surtout dans les queues de journaux, enfin, les fins } \\
\text { de journal, } \\
\text { especially in the tails of bulletin, well, at the ends } \\
\text { of bulletin, }\end{array}$ \\
\hline 4 & $\begin{array}{l}\text { il faut des images un peu de bonnes nouvelles, des } \\
\text { images, } \\
\text { You need to have images of good news, images, }\end{array}$ \\
\hline 5 & $\begin{array}{l}\text { des petites historiettes, } \\
\text { charming anecdotes, }\end{array}$ \\
\hline 6 & $\begin{array}{l}\text { voire des histoires croquingnolesques, qui } \\
\text { plaisent. } \\
\text { even nice stories, which are appealing. }\end{array}$ \\
\hline 7 & $\begin{array}{l}\text { Voilà. Alors, avec des dérives, quoi. } \\
\text { That's it. So, with drifts, well. }\end{array}$ \\
\hline 8 & $\begin{array}{l}\text { Je ne sais pas. } \\
\text { I don't know. }\end{array}$ \\
\hline 9 & $\begin{array}{l}\text { Dernièrement, on m'a demandé de faire un truc sur } \\
\text { une femme } \\
\text { Recently, I have been asked to do a thing about a } \\
\text { woman }\end{array}$ \\
\hline 10 & $\begin{array}{l}\text { qui avait chanté pendant soixante heures en Corée, } \\
\text { who had sung for } 60 \text { hours in Korea, }\end{array}$ \\
\hline 11 & $\begin{array}{l}\text { dans un karaoké en Corée du Sud, } \\
\text { in a karaoke in South Korea, }\end{array}$ \\
\hline 12 & $\begin{array}{l}\text { parce que son mari avait le cancer, } \\
\text { because her husband had cancer, }\end{array}$ \\
\hline 13 & $\begin{array}{l}\text { enfin, pour lui donner du courage. } \\
\text { well, to keep his spirits up. }\end{array}$ \\
\hline 14 & $\begin{array}{l}\text { Bon, là-dessus, eh bien, moi j'ai quelques doutes sur } \\
\text { ce choix-là. } \\
\text { Well, about it, well, I have some doubts about such } \\
\text { a choice. }\end{array}$ \\
\hline
\end{tabular}

\section{$\mathrm{R}=$ Researcher; $\mathrm{J}=$ Journalist.}

a Due to the vast amount of data and the topic at issue, the transcripts do not display all the phenomena observed in talk-in-interaction (e.g. rising/falling intonations, hesitations or overlaps). Our data is originally in French. We provide an interlinear translation in English. Apart from excerpts 4 and 8, we use the following conventions: the speaker's name is indicated on the left; the numbers on the left refer to the transcribed lines; ${ }^{*}$ word $^{*}=$ the speaker is reading; $(\ldots)=$ pause; $[\ldots]=$ data not transcribed; $(($ word $))=$ description; $\mathrm{xxx}=$ inaudible talk.

"refer[ence] to particular elements only identified by the fact that they are part of the class denoted by the noun" (Riegel, Pellat \& Rioul, 2014, p. 293, our translation). Thus, «histoire» - in association with the derogatory forms and the indef- inite article - refers to a genre that corresponds with soft news in contrast to hard news (see Tuchman, 1973; Bell, 1991; Cotter, 2010, p. 135-145).

In excerpt 2, the researcher asks journalist CA about his news-writing routines

\section{Excerpt 2: "To relay a story that I did not know" (March 5, 2007)}

\begin{tabular}{|c|c|}
\hline $1 \mathrm{R}$ & $\begin{array}{l}\text { Est-ce qu'il y a [...] des étapes types dans la rédac- } \\
\text { tion d'un reportage? } \\
\text { Are there any typical steps in the writing of a report? } \\
{[\ldots]}\end{array}$ \\
\hline $2 \mathrm{~J}$ & $\begin{array}{l}\text { D'abord, savoir de quoi je vais parler. } \\
\text { First of all, knowing what I'm going to talk about. } \\
{[\ldots]}\end{array}$ \\
\hline 3 & $\begin{array}{l}\text { II y a des sujets que je découvre [...] deux, trois } \\
\text { heures avant le téléspectateur. } \\
\text { There are topics / find out about two or three hours } \\
\text { before the audience does. }\end{array}$ \\
\hline 4 & $\begin{array}{l}\text { Je n'ai pas la science infuse, et [... ] aucun journal- } \\
\text { iste ne l'a. } \\
\text { I'm not all-knowing, and I don't know any journalist } \\
\text { who is all-knowing. }\end{array}$ \\
\hline 5 & $\begin{array}{l}\text { Donc, forcément, pour être capable de retransmettre } \\
\text { une histoire } \\
\text { So, necessarily, to be able to relay a story }\end{array}$ \\
\hline 6 & $\begin{array}{l}\text { que je ne connaissais pas [...] moi-même trois } \\
\text { heures avant le téléspectateur } \\
\text { that I did not know [...] myself three hours before } \\
\text { the audience }\end{array}$ \\
\hline 7 & $\begin{array}{l}\text { qui lui, ne la connaît pas, il y a forcément une } \\
\text { méthode. } \\
\text { who don't know about it, there is necessarily a } \\
\text { method. }\end{array}$ \\
\hline 8 & $\begin{array}{l}\text { C'est ça qui fait le métier de journaliste: comment } \\
\text { rendre } \\
\text { This is what makes the craft of journalist: how to } \\
\text { make }\end{array}$ \\
\hline 9 & $\begin{array}{l}\text { comestible, enfin, compréhensible, intelligible, une } \\
\text { histoire } \\
\text { a story edible, well, understandable, intelligible }\end{array}$ \\
\hline 10 & $\begin{array}{l}\text { dans un cadre donné. Et ce cadre, il est clair. } \\
\text { in a given framework. And this framework is clear. }\end{array}$ \\
\hline 11 & $\begin{array}{l}\text { Ce n'est pas cinq mille ou six signes dans un journal. } \\
\text { This is not five thousand or six thousand characters } \\
\text { in a newspaper. }\end{array}$ \\
\hline 12 & $\begin{array}{l}\text { Mais c'est à la télévision. C'est une minute, une } \\
\text { minute quinze } \\
\text { But this is on television, this is one minute, one } \\
\text { minute fifteen seconds, }\end{array}$ \\
\hline 13 & $\begin{array}{l}\text { une minute trente, deux minutes éventuellement. } \\
\text { Voilà. } \\
\text { one minute thirty, two minutes maybe. That's it. }\end{array}$ \\
\hline
\end{tabular}

(1.1). In his answer, the journalist frames the need for a method. 
According to the journalist, a news-writing method is needed for three reasons: his epistemic status, he is not all-knowing (1.4); the task at hand, to relay a story (1.5); the genre, a television news (1.10-13). «Histoire» appears twice: firstly, relating to an epistemic issue (knowing/not knowing, 1.5-7); secondly, relating to an information processing issue (as indicated by the "assimilation" adjectives understandable, intelligible and edible). In both instances, "histoire" refers to an already existing set of information that is caught up in specific constraints relating to news production as well as news broadcasting. "Histoire" is thus differentiated from the material framework in which it is realised (1.10-13). To sum up, in excerpt 2, «histoire» refers to a set of information lifted from a context to another.

Excerpt 3 displays another meaning of "histoire». Here, the researcher interrogates the journalist about his collaboration network in the workplace. Apart from cutters and nearby colleagues, journalist CA talks about his contacts with the hierarchy and, more precisely, the producer of the news bulletin.

Excerpt 3: “I have already completely built my story" (March 5, 2007)

\begin{tabular}{|c|c|}
\hline $1 \mathrm{R}$ & $\begin{array}{l}\text { Avec qui est-ce que tu discutes des reportages? } \\
\text { Who do you speak to about reports? } \\
{[\ldots]}\end{array}$ \\
\hline $2 \mathrm{~J}$ & $\begin{array}{l}\text { Il peut arriver que le chef d'édition me dit: " Mais tu } \\
\text { as vu ces images } \\
\text { It can happen that the producer tells me: "Did you see } \\
\text { this footage }\end{array}$ \\
\hline 3 & $\begin{array}{l}\text { qui arrivent à 19:15? II faut absolument ça au début. } \\
\text { that come in at 7:15 pm? You absolutely have to put } \\
\text { it in the beginning. }\end{array}$ \\
\hline 4 & $\begin{array}{l}\text { C'est les dernières". Je dis: "Ecoute, ça ne va pas. } \\
\text { Ecoute, tu as vu ça? } \\
\text { This is the latest one". I say: "Listen, no way. Listen, } \\
\text { did you see that? }\end{array}$ \\
\hline 5 & $\begin{array}{l}\text { Ecoute, j'ai déjà tout construit mon histoire. } \\
\text { Listen, I have already completely built my story. }\end{array}$ \\
\hline 6 & $\begin{array}{l}\text { Le montage est déjà à trois quart terminé ". } \\
\text { The cutting is already almost done." }\end{array}$ \\
\hline 7 & $\begin{array}{l}\text { Là, il peut y avoir une interaction, à la limite, des fois, } \\
\text { autoritaire, } \\
\text { At that point, there can be an interaction, sometimes } \\
\text { nearly authoritarian, }\end{array}$ \\
\hline 8 & $\begin{array}{l}\text { mais il peut y avoir des discussions. } \\
\text { but we can have a chat. }\end{array}$ \\
\hline
\end{tabular}

The journalist is portraying these hierarchical relationships through a constructed dialogue (Tannen, 2007) that allows him to differentiate his position as reporter from that of producer. Of particular interest for us is the fact that "histoire" appears in a talk simulating an interaction taking place in the newsroom. According to journalist CA's simulation, it does not seem to be implausible to encounter the word «histoire» in the actual talk of media practitioners engaged in their daily routine. In the animation of the newsroom dialogue made by the journalist, "histoire" refers neither to a genre (excerpt 1), nor to a set of information (excerpt 2) but rather to the semiotic product he made, as indicated by the use of a "production" verb (1.5: built) as well as the first person markers (1.5: I have, $m y)$. It is worth emphasizing that "story" seems to refer to a semiotic realization, entangling verbal and audio-visual means, and not only to a symbolic one.

To sum up, the use of "histoire» enables the journalist to describe diverse aspects of his work, ranging from news classifications and ethical issues to epistemic statuses and practical concerns.

\subsection{Saying "histoire» to produce a broadcast news item}

The second part of the case study focuses on the production of a television news item about the crash of an aircraft in Indonesia on March 7, 2007 for the news bulletin's noon edition (see excerpt 4).

More precisely, we focus on the interaction between journalist CA and a cutter in the cutting-room. Our analysis is structured in three moments that correspond with the use of «histoire» before (2.2.1.), during (2.2.2.) and after (2.2.3.) the writing of the news item.

\subsubsection{Saying "histoire» before the writing}

Before beginning the writing, the journalist and the cutter swing between two segments of footage that could be used in the opening of the news item (Merminod, 2016). Then, they negotiate its structuring (excerpt 5, below).

The temporary structuring of the news items displays the following parts: 
Excerpt 4: Yogyakarta news report (March 7, $2007,12: 45-12: 48$ pm)
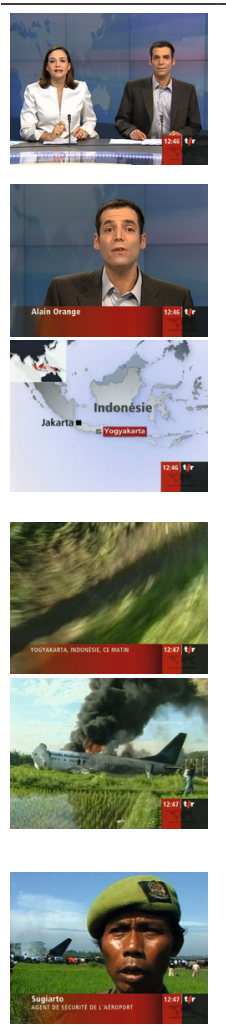

Witt

\begin{tabular}{l|l} 
Anc1 & $\begin{array}{l}\text { We begin with news from another } \\
\text { aviation catastrophe this morning } \\
\text { in Indonesia. }\end{array}$ \\
\end{tabular}

It is a Boeing 737 of the national company Garuda that crashed upon landing on the island of Java killing about twenty people. Most of the passengers were Indonesians but a delegation of Australian diplomats and journalists was also on board. Warning some footage might be shocking They are commentated on by CA.

A few moments after the crash the desperate escape, far from the Boeing, for one of the survivors. This passenger is not yet safe but his camera is on. No fewer than one hundred and twelve passengers, among the one hundred and thirty-three transported by the Indonesian company Garuda, survived, and six out of seven members of the crew. But many are injured. The statement of a security officer at the airport in Yogyakarta.

I heard two explosions and I pulled four people out of the airplane, safe and sound. About thirty passengers were already outside, and they too were all alive.

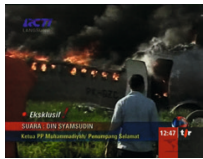

Over

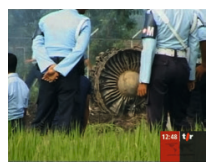

Excerpt 5: "And we tell a little bit of the story" (March 7, 2007, 11:00-11:01 a.m.)

\begin{tabular}{|c|c|}
\hline $1 \mathrm{~J}$ & $\begin{array}{l}\text { Bon, on va commencer quelque chose une scène } \\
\text { comme ça. } \\
\text { So, we're going to start with something like a scene } \\
\text { like this. }\end{array}$ \\
\hline 2 & ((J does a large circular movement with his hand)) \\
\hline $3 C$ & $\begin{array}{l}\text { J'ai quand même envie de commencer avec le gars } \\
\text { qui court, quoi, } \\
\text { In my opinion, we should start with the guy who is } \\
\text { running, well, }\end{array}$ \\
\hline 4 & $\begin{array}{l}\text { et puis on laisse après dix secondes. } \\
\text { and then we leave ten seconds after. }\end{array}$ \\
\hline $5 \mathrm{~J}$ & $\begin{array}{l}\text { Voilà, l'avion popoa, les gens qui s'enfuient, qui } \\
\text { arrivent } \\
\text { Right, the plane popo, the people running away, } \\
\text { who manage }\end{array}$ \\
\hline 6 & $\begin{array}{l}\text { à se sauver, le sonore du } \\
\text { to save themselves, the audio of }\end{array}$ \\
\hline $7 \mathrm{C}$ & $\begin{array}{l}\text { Ouais. } \\
\text { Yeah. }\end{array}$ \\
\hline $8 \mathrm{~J}$ & $\begin{array}{l}\text { de la sécurité de l'aé-, du gardien de l'aéroport qui } \\
\text { dit: } \\
\text { of the security of the air-, of the security guard of the } \\
\text { airport who says: }\end{array}$ \\
\hline $9 \mathrm{C}$ & $\begin{array}{l}\text { C'est dingue, regarde les gens! } \\
\text { That's crazy, look at the people! }\end{array}$ \\
\hline $10 \mathrm{~J}$ & $\begin{array}{l}\text { "J'ai vu les gens réussir à se casser". } \\
\text { "I saw people managing to get out of there." }\end{array}$ \\
\hline 11 & $\begin{array}{l}\text { Puis, après, on raconte un peu l'histoire, hein? } \\
\text { And then we tell a little bit of the story, isn't it? }\end{array}$ \\
\hline $12 \mathrm{C}$ & $\begin{array}{l}\text { Ils sont complétement sonnés, quoi. Regarde comme } \\
\text { ils marchent, quoi. } \\
\text { They are completely knocked out. Look how they are } \\
\text { walking. }\end{array}$ \\
\hline 13 & $\begin{array}{l}\text { C'est dingue, hein? } \\
\text { That's crazy, no? }\end{array}$ \\
\hline $13 \mathrm{~J}$ & $\begin{array}{l}\text { Non mais dis hein, il y a de quoi, hein? } \\
\text { Seriously, that's something, no? }\end{array}$ \\
\hline $14 \mathrm{C}$ & $\begin{array}{l}\text { Complétement choqués, hein? } \\
\text { Completely shocked, isn't it? }\end{array}$ \\
\hline
\end{tabular}

$\mathrm{J}=$ Journalist; $\mathrm{C}=$ Cutter.

a Either this sound imitates the plane's trajectory in the rice field or it means "and so on and so forth."

in the beginning of the final news items, before the account of the security guard, which itself matches part D. This allows us to hypothesize that part E, only labelled as "the story" (excerpt $5,1.11$ ) in the temporary structuring, corresponds with the recounting of the crash proceedings (excerpt 4: "At the moment of landing ... and burning up completely."). Thus, it seems that «histoire» refers to the series of events that led to the crash. If there are images of the consequences of the crash (people flee- 
ing and saving themselves, the plane burning, etc.), there are no images of the crash itself. Thus, at this specific moment of the news production, the use of "histoire», or more precisely of "raconter l'histoire", enables the journalist to contrast a part that can be only verbally recounted with parts that can be illustrated with some prefabricated material. Besides, the association of «histoire» with a definite article (1.11: $l$ ) and the absence of any further specification tend to place the crash episode as the sole story or, at least, as the central one.

\subsubsection{Saying «histoire» during the writing ${ }^{5}$}

"Histoire" is then used twice during the writing of the news item's first segment: "A few moments after the crash, the desperate escape, away from the Boeing, for one of the survivors. This passenger is not yet safe but his camera is on." The writing of the news item's first segment is divided into three moments (Merminod, 2016):

1 From 11:09 to 11:10: "the desperate escape," "far from the Boeing" and "of one of the survivors."

Result: "The desperate escape far from the Boeing of one of the survivors."

2 From 11:12 to 11:13: "his camera is on" and "a few moments after the crash."

Result: "A few moments after the crash, the desperate escape far from the Boeing of one of the survivors. His camera is on."

3 From 11:15 to 11:17: "this passenger is not yet safe" and "but."

Result: "A few moments after the crash, the desperate escape far from the Boeing of one of the survivors. This passenger is not yet safe but his camera is on."

The first "histoire» ("it is implausible, that story of shit[s]," excerpt 6, 1.2-3) appears at 11:11 between the first and second writing phases; the second "histoire" ("it is unbelievable, that story," excerpt 7, 1. 6) emerges at 11:14 between the second and third

5 The writing of the news item has been diversly analysed in previous works (see Burger, 2011; Perrin, 2013; Merminod, 2016; Zampa, 2017; Merminod \& Burger, forthcoming). writing phases. Both segments display a similar syntactic format, a right dislocation featuring a demonstrative determiner. Right dislocation is usually used in French talk-in-interaction as a routinized format for emphasising an assessment (Pekarek Doehler, De Stefani \& Horlacher, 2015, p. 133-160). This is the case for both instances: the first case sees a negative assessment while the second sees a positive one. Let's examine them in turn.

In excerpt 6 , the practitioners have agreed on how the report would begin. They work separately in silence (1.1), without looking at each other. The journalist is looking for a development that fits with

$\begin{aligned} & \text { Excerpt 6: “Anyway, it is implausible, that story } \\
& \text { of shit" (March 7, 2007, 11:11 a. m.) }\end{aligned}$
\begin{tabular}{l|l}
\hline 1 \\
J
\end{tabular}
$\begin{aligned} & \text { (14) } \\
& \text { C'est quand même invraisemblable } \\
& \text { Anyway, it is implausible, } \\
& \text { cette histoire de merde(s). } \\
& \text { that story of shit/s). } \\
& \text { (11) }\end{aligned}$
5 C
6

his first sentence: "The desperate escape, away from the Boeing, for one of the survivors."

Excerpts 6 shows these "circumstances in which we will audibly address statements to ourselves, blurt out imprecations, and utter 'response cries,' such as, Oops!, Eek!, and the like $[\ldots]$, we will seek some response from those who can hear us, but not a specific reply. No doubt the intent is to provide information to everyone in range, but without taking the conversational floor to do so. What is sought is not hearers but overhearers, albeit intended ones" (Goffman, 1981, p. 136-138). The journalist, looking to develop his text, displays his reflexive activity (1.2-3) while the 
cutter displays the technical problems he has with his machine (1.5).

By comparison with the other instances, the meaning of "histoire» in excerpt 6 seems at first to be abstruse for an external observer. «Histoire de merde(s) » could mean "shitty story." Nevertheless, neither the journalist's tone, nor his stance during the overall news production is consistent with such an assumption. Besides, it is difficult to know what «histoire de merde(s) " is referring to: the demonstrative determiner (1.3: cette) can point at the event the journalist is writing about, at the writing itself as well as at something completely different. Actually, "histoire de merde(s)" rather seems to be uttered in relationship with a previous event, an event that happened two hours earlier in the newsroom, just between the 9:15 am and 9:30 am editorial meetings.

The crash story was assigned to journalist CA during the 9:15 am meeting. Further to this, the journalist and his colleagues had a break in the same room. Two of his colleagues began to list the many disasters hitting Indonesia back then: $t s u$ nami, earthquake, terrorism, plane crash, mudslide, flooding. Then, playfully, they suggested different headlines, such as "how can one be Indonesian?," and insisted on the following one several times: "Indonesia, shit(s) funnel of the world," even calling out to the international desk editor and emphasizing the inappropriateness of such a headline. Journalist CA did not participate in their playful framing of the events but observed it. Then, he joined his colleagues' conversation and listed with them the series of disasters: tsunami, H5N1, mudslide, terrorism, ferryboat accident, plane crash. After that, journalist CA brought to their attention the fact that the researchers' camera was still running. Underlining again the inappropriateness of their framing, his two colleagues replied by alluding to the possibility that the recording would leak out on YouTube ${ }^{6}$.

6 Happily, the researchers were allowed to keep the recording. This event is interesting in many respects. The newsroom is sometimes considered as a backstage region in contrast to the public performance that a
In light of this event, «histoire de merde(s)» rather seems to mean "story about shit(s)," "shit" being the series of disasters experienced by Indonesia back then. In that case, «histoire» appears to refer to a frame that the journalist chose not to select.

Another instance of "histoire» appears a few minutes later. The journalist and the cutter are probing different descriptions of the actions carried out by the individual filming the event (Merminod \& Burger, forthcoming). The journalist has already written a text that describes what happened in the footage: "A few moments after the crash, the desperate escape, away from the Boeing, for one of the survivors. His camera is on." He is now wondering whether or not he has to insist on the fact that such a critical moment (fleeing from a plane after a crash) has been recorded (1.4-5).

In excerpt 7, «histoire», associated with a demonstrative determiner (1.6) and being the subject of an assessment, refers obviously to the experience of the individual filming the scene. It is worth noting that the story's assessment is similar to the assessments expressed during the 9:15 am meeting, the first time the journalist heard about the escape experience and its images. At 9:15 am, while the international desk editor was commenting on the noteworthiness of the footage, a journalist from the international desk observed: "it is unbelievable that people managed to get out of the plane like that"; having insisted on the way it was shot, the desk editor replied: "yes it is unbelievable." It seems that, in excerpt 7 as well as in the 9:15 am meeting, the assessment of the experience is mixed up with an assessment of the footage that

television news bulletin is. The "shits' funnel" event, taking place between two scheduled events that punctuate the newsroom official business, shows, in a way, the backstage in the backstage: "Here costumes and other parts of personal front may be adjusted and scrutinized for flaws. Here the team can run through its performance, checking for offending expressions when no one is present to be affronted by them [...]. Here the performer can relax" (Goffman, 1959, p. 115). 


\begin{tabular}{|c|c|}
\hline $1 \mathrm{~J}$ & $\begin{array}{l}\text { ((looking at his screen) }){ }^{*} \text { Quelques instants après } \\
\text { le crash, } \\
\text { ((looking at his screen)) *A few moments after the } \\
\text { crash, }\end{array}$ \\
\hline 2 & $\begin{array}{l}\text { la fuite éperdue, loin du Boeing, de l'un des sur- } \\
\text { vivants. } \\
\text { the desperate escape, far from the Boeing, for one } \\
\text { of the survivors. }\end{array}$ \\
\hline 3 & $\begin{array}{l}\text { Sa camera est enclenchée. Virgule* euh } \\
\text { His camera is on. Comma* er }\end{array}$ \\
\hline 4 & $\begin{array}{l}\text { Toute la scène est immortalisée. } \\
\text { The whole scene has been captured. }\end{array}$ \\
\hline 5 & $\begin{array}{l}\text { ((slightly leaning towards C) II faut le dire, non? Ça, } \\
\text { quand même. } \\
\text { ((slightly leaning towards C)/ We must say it, no? } \\
\text { This, anyway. } \\
\text { Looking at his screen, during } 18 \mathrm{sec}, \mathrm{J} \text { mumbles } \\
\text { words he has already written. }\end{array}$ \\
\hline $6 \mathrm{~J}$ & $\begin{array}{l}\text { ((turning towards C) ) C'est incroyable, cette histoire. } \\
\text { ((turning towards C)) It is unbelievable, that story. }\end{array}$ \\
\hline 7C & $\begin{array}{l}\text { Ouais, c'est ((leaning back and looking at his } \\
\text { screen)). } \\
\text { Yeah, that's ((leaning back and looking at his } \\
\text { screen)). }\end{array}$ \\
\hline $8 \mathrm{~J}$ & $\begin{array}{l}\text { Looking at his screen, } \mathrm{J} \text { mumbles during } 12 \mathrm{sec} \text {. } \\
\text { II faut faire attention de pas avoir de jugement de } \\
\text { valeur. } \\
\text { We have to be cautious not to make value judg- } \\
\text { ments. }\end{array}$ \\
\hline 9 & $\begin{array}{l}\text { Leaning forward, C starts his work on the footage } \\
\text { again }\end{array}$ \\
\hline 10 & $\begin{array}{l}\text { C'est absolument incroyable, ouais. } \\
\text { It is absolutely unbelievable, yeah. }\end{array}$ \\
\hline
\end{tabular}

shows it. In a way, the cutter's reaction, acknowledging the journalist's assessment (1.7) and even repeating it (l.10: "it is absolutely unbelievable") while continuously looking at the footage, tends to strengthen this blending.

To sum up, during the writing, "histoire» appears twice: on the one hand, the journalist refers to a frame that locates the crash as an instance in a series of tragic events and relates to a master narrative about Indonesia; on the other hand, the journalist refers to an event that is considered to be noteworthy owing to the fact that the semiotic material bears witness to the unusual experience of fleeing from a crashed plane. Although different, the two assessments echo what has been said by colleagues before the actual writing of the news item.

\subsubsection{Saying "histoire» after the writing} "Histoire» is used a last time while the news-making production process comes to an end. At 12:20 pm, in the cutting-room, the producer of the evening edition mentions the fact that a Swiss-Italian radio journalist was in the plane and was able to phone the radio station to record an account of his experience. Journalist CA decides not to include the account in the noon report. Nevertheless, at $12: 28 \mathrm{pm}$, having recorded the news item's voice-over, he begins to look for the Swiss-Italian radio journalist's account the producer previously mentioned. Firstly, the journalist checks the news wires, typing in his search engine "indonésie" (Indonesia) and "tessinois» (Swiss-Italian), but he finds nothing. Then, at 12:29 pm, he goes on the broadcasting corporation website (tsr.ch), which devotes one page of the online news edition to the plane crash. The lead and the first paragraph of the webpage refer to the Swiss-Italian journalist (below, an English translation of a part of the webpage):

\section{Excerpt 8: TSR online news edition about the Yogyakarta crash (March 7, 2007)}

Crash in Indonesia: Around Twenty Dead

07.03.2007 07:29

A Boeing 737, which transported 140 persons, caught fire by failing to land on Wednesday on the island of Java. [...] A Swiss-Italian radio journalist survived the crash.

Alessandro Bertelotti is a RSI [Swiss-Italian Radio] correspondent for the Far East. According to him, the reason for the crash was the excessive speed at the moment of landing.

[...]

On this topic

RSR [Swiss-French Radio] - The report of Solenne Honorine March 7. Morning Edition.

The journalist finds a mention of the Swiss-Italian journalist's experience on the website but he does not find the audio recording of his account. On the other hand, the webpage provides him with a report by Solenne Honorine, a Swiss-French radio correspondent in Jakarta. From 12:31 to $12: 32 \mathrm{pm}$, the journalist listens to the report. Further to this, the journalist comments on what he has (not) found on the website. 


\begin{tabular}{|c|c|}
\hline & $\begin{array}{l}\text { journalist" (March 7, 2007, 12:32- } \\
\text { 12:33 p.m.) }\end{array}$ \\
\hline \multirow[t]{2}{*}{$1 \mathrm{~J}$} & $\begin{array}{l}\text { Oh, pff ((sigh)). } \\
\text { Oh, pff ((sigh)). }\end{array}$ \\
\hline & $\begin{array}{l}\text { During } 17 \mathrm{sec} ., \mathrm{J} \text { looks at his screen, then at C's } \\
\text { screen, then at his own again. }\end{array}$ \\
\hline $2 \mathrm{~J}$ & $\begin{array}{l}\text { Bon. (...) Qu'est-ce que xxx } \\
\text { Well. (...) What xxx }\end{array}$ \\
\hline 3 & $\begin{array}{l}\text { cette histoire du journaliste tessinois } \\
\text { that story of the Swiss-Italian journalist }\end{array}$ \\
\hline 4 & $\begin{array}{l}\text { Mais enfin, bon, xxx. } \\
\text { But anyway, well, xxx. }\end{array}$ \\
\hline 5 & $\begin{array}{l}\text { Il y a le témoignage d'une correspondante à Jakarta } \\
\text { There is the account of a correspondent in Jakarta }\end{array}$ \\
\hline 6 & $\begin{array}{l}\text { de la télé ro-, de la radio romande. } \\
\text { of the Swiss-French TV, of the Swiss-French Radio. }\end{array}$ \\
\hline 7 & $\begin{array}{l}\text { Mais pas particulièrement intéressant. } \\
\text { But not really interesting. }\end{array}$ \\
\hline
\end{tabular}

In excerpt 9, the journalist is still wearing the headphones he used to listen to the French correspondent's report, and is looking only at the screens when talking. As for the cutter, he is working on the report's soundtrack and does not pay attention to the journalist's talk. Both the practitioners appear to be focused only on their own tasks. The noises coming from the soundtrack, as well as the fact that the journalist mumbles, make the beginning of this part (1.2) difficult to transcribe accurately. At line 3, "histoire» is associated with a demonstrative determiner (1.3: cette) and a prepositional group (1.3: "of the Swiss-Italian journalist"): thus, it does not refer to the story recounted by the Swiss-Italian journalist but rather to the story about him. More precisely, because of its twofold specification through a deictic marker and a description, "histoire» can refer to the experience of the journalist-survivor as well as to its previous mentions by the producer and on the website.

To summarize briefly the analyses carried out in the second part of our case study, we found that "histoire" is used as a reflexive means, enabling the journalist to orient himself in the very practical tasks entailed by the production of a multimodal artefact, such as structuring the news item or assessing available frames, semiotic resources and sources.

\section{Conclusion}

This article has examined how, when and why the word "histoire» is used in the context of newsroom activities. It has shown the presence of three different meanings of «histoire»: "histoire» as a genre, "histoire» as a set of information and "histoire" as a semiotic product. If these three meanings emerged when the journalist reflected on broadcast news production, the actual news production process favoured the use of "histoire» as a set of information. During the broadcast news production, the journalist used "histoire» before, during and after the writing of the news item. "Histoire» enables him to distinguish information conveyed by different semiotic means as well as to underline the (ir)relevance of particular production choices. "Histoire» referred to particular events but also to individual experiences and journalistic frames. Regarding the reference to events, it concerned the central event (the crash) as well as some background information (causes, consequences). It was further used not only to refer to what happened in the world but also to what happens in the newsroom.

The case study provides us with a better understanding of the use of the narrative lexicon in the newsroom and allows us to reconsider some of the assumptions surrounding the narrative nature of news. It echoes and puts into perspective the statement of Tuchman:

\footnotetext{
[A]t least in part, reporters may speak of stories among themselves rather than about events. They may see the everyday world and its supporting documents in terms of the product they are to manufacture - a news story. (Tuchman, 1976, p. 95)
}

More than seeing the world in terms of a news story, journalists navigate between different stories. In other words, they sort through narrative configurations that vary in terms of spatiotemporal and experiential extensions. Theses narrative configurations orient the journalists in their everyday work and, at the same time, are constantly assessed by the latter in view of 
the tasks at hand. Thus, if the case study corroborates the idea that the newsroom is full of stories that make news, it leads us to go beyond the myth of journalistic storytelling, by taking into account the local rationalities that, as exemplified here, ground the use of "histoire» ("story").

Story formulations in the newsroom still remain largely under-explored, and we would like to emphasize the need for further investigation that focuses not only on one participant - the pattern of use we described could be just idiosyncratic - but extends the analysis to a community of practice. Besides, as underlined in the introduction, "story" is not "histoire», neither $"$ Geschichte» ${ }^{7}$, nor "storia". Thus, our reflection on story formulation calls for a crosslinguistic comparison as well as a crossmedia inquiry (for instance: by contrasting the use of "story" between written and broadcast news). Likewise, it could be worth tracking the use of "story" in the news (rather than only in the newsroom) through different timeframes: if it is not unusual to encounter the word "story" in the news nowadays ${ }^{8}$, was it the case ten or twenty years ago?

Explorations in these directions would not only show that corresponding words are used in slightly different ways depending on the language, the culture, the time and the place. They could be a valuable means to grasp the changes that occurred and are occurring in the journalistic ideologies and practices of rendering events, experiences and worlds.

7 As observed by Perrin \& Wyss (2016): «Erzählen ist ein Sprachhandlungsmuster, das stark mit dem Konzept Geschichte verbunden ist: Man kann im Deutschen keine Fakten erzählen, keine Botschaften, keine Nachrichten, nur Lügen oder Geschichten und Spezialformen davon, wie Sagen oder Märchen» (Perrin \&Wyss, 2016, p. 244).

8 As in the following instance: "Brexit. Follow this story everywhere. BBC News" (BBC One, 08.05.2017).

\section{Acknowledgement}

This research was supported by a grant from the Swiss National Science Foundation (P1LAP1_164898).

This paper has greatly benefited from discussions with Alexandra Georgakopoulou. I'm also grateful to the anonymous reviewers and the editors of the thematic section. All caveat apply.

\section{References}

Adam, J.-M. (2011). Genres de récits: Narrativité et généricité des textes. Bruxelles: Academia.

Arquenbourg, J. (2005). Comment les récits d'information arrivent-ils à leurs fins? Réseaux, 132(4), 27-50.

Baroni, R. (2016). Un feuilleton médiatique forme-t-il un récit? Belphégor, 14. doi:10.4000/belphegor.660

Baroni, R., Pahud, S., \& Revaz, F. (2006). De l'intrigue littéraire à l'intrigue médiatique: le feuilleton Swissmetal. A Contrario, 4(2), 125-143.

Barthes, R. (1964). Structure du fait divers. In Barthes, Roland, Essais critiques (pp. 188198). Paris: Seuil.

Barthes, R. (1957). Mythologies. Paris: Seuil.

Bell, A. (1998). The discourse structure of news stories. In A. Bell \& P. Garret (Eds.), Approaches to media discourse (pp. 64-104). Oxford: Blackwell.

Bell, A. (1994). Telling stories. In D. Graddol \& O. Boyd-Barrett (Eds.), Media Texts, Authors and Readers: A Reader (pp. 100-118). Clevedon: Multilingual Matters.

Bell, A. (1991). The Language of News Media. Oxford: Blackwell.

Bird, E., \& Dardenne, R. (2009). Rethinking news as myth and storytelling. In K. Wahl-Jorgensen \& T. Hanitzsch (Eds.), The Handbook of Journalism Studies (pp. 205-217).New York: Routledge.

Bird, E., \& Dardenne, R. (1988). Myth, chronicle, and story: Exploring the narrative qualities of news. In J.W. Carey (Ed.), Media, myth, and narratives: Television and the press (pp. 67-86). Newbury Park: Sage.

Burger, M. (2011). Une considération praxéologique du désaccord polémique: Ce 
qu'informer dans les médias veut dire. Semen, 31, 61-80.

Burger, M. (Ed.) (2018). Investigating journalism practices. Combining newsroom ethnography and nedia discourse analysis. Lausanne: Centre de Linguistique et des Sciences du Langage.

Cotter, C. (2010). News Talk. Investigating the Language of Journalism. Cambridge: Cambridge University Press.

Dardenne, R. (2005). Journalism. In D. Herman, M. Jahn \& M.-L. Ryan (Eds.), Routledge Encyclopedia of Narrative Theory (pp. 267269). New York: Routledge.

De Fina, A., \& Georgakopoulou, A. (2012). Analysing narrative. Discourse and sociolinguistic perspectives. Cambridge: Cambridge University Press.

Deppermann, A. (2011). The study of formulations as a key to an Interactional Semantics. Human Studies, 34(2), 115-128.

Dubied, A. (2004). Les dits et les scènes du fait divers. Geneva: Droz.

Eliade, M. (1963). Myth and Reality. New York: Harper \& Row.

Fludernik, M. (2005). Histories on narrative theory (II): From structuralism to the present. In J. Phelan \& P. J. Rabinowitz (Eds.), $A$ Companion to Narrative Theory (pp. 3659). Malden: Blackwell.

Genette, G. (1998). Die Erzählung. Munich: Fink.

Georgakopoulou, A. (2015). Small stories research: Methods-analysis-outreach. In A. De Fina \& A. Georgakopoulou (Eds.), The handbook of narrative analysis (pp. 255271). Oxford: Wiley-Blackwell.

Georgakopoulou, A. (2007). Small stories, interaction and identities. Amsterdam: John Benjamins.

Goffman, E. (1981). Forms of talk. Oxford: Blackwell.

Goffman, E. (1974). Frame analysis. An essay on the organization of experience. Middlesex: Penguin.

Goffman, E. (1959). The presentation of self in everyday life. New York: Anchor Books.

Greimas, A. J. (1966) Sémantique structural. Paris: Presse universitaires de France.

Herman, D. (2009). Basic Elements of Narrative. Oxford: Wiley-Blackwell.
Herman, D. (2007). The Cambridge companion to narrative. Cambridge: Cambridge University Press.

Hühn, P., Meister, J. C., Pier, J., \& Schmid, W. (Eds.) (2014). Handbook of narratology. Berlin: Walter De Gruyter.

Hyvärinen, M. (2006). Towards a conceptual history of narrative. In M. Hyvärinen, A. Korhonen \& J. Mykkänen (Eds.), The travelling concept of narrative (pp. 20-41). Helsinki: Helsinki Collegium for Advanced Studies.

Jacobs, G. (2017). Organizations and corporate communication: Linguistic ethnography in the newsroom. In C. Cotter \& D. Perrin (Eds.), The Routledge handbook of language and media (pp. 178-189). London: Routlegde.

Jamet, C., \& Jannet, A.-M. (1999). Les stratégies de l'information. Paris: L'Harmattan.

Jaworski, A., Coupland, N., \& Galasinski, D. (Eds.) (2004). Metalanguage. Social and ideological perspectives. Berlin: Mouton de Gruyter.

Labov, W., \& Waletzky, J. (1967). Narrative analysis: Oral versions of personal experience. In J. Helm (Ed.), Essays on the verbal and visual arts (pp. 12-44). Seattle: University of Washington Press.

Lévi-Strauss, C. (1971). Mythologiques. L'homme nu. Paris: Plon.

Lévi-Strauss, C. (1968). Mythologiques. L'origine des manières de table. Paris: Plon.

Lévi-Strauss, C. (1967). Mythologiques. Du miel aux cendres. Paris: Plon.

Lévi-Strauss, C. (1964). Mythologiques. Le cru et le cuit. Paris: Plon.

Lits, M. (2008). Du récit au récit médiatique. Bruxelles: De Boeck.

Luginbühl, M., Schwab, K., \& Burger, H. (2004). Geschichten über Fremde. Eine linguistische Narrationsanalyse von Schweizer Fernsehnachrichten von 1957 bis 1999. Bern: Peter Lang.

Lule, J. (2001). Daily news, eternal stories: The mythological role of journalism. New York: Guilford Press.

Malinowski, B. (1926). Myth in primitive psychology. London: Norton.

Merminod, G. (2016). Telling stories from the newsroom: a linguistic ethnographic account of dramatization in broadcast news. Working Papers in Urban Language \& Lit- 
eracies, 197. Retrieved from https://www. kcl.ac.uk/sspp/departments/education/ research/ Research-Centres/ldc/publications/workingpapers/search.aspx.

Merminod, G., \& Burger, M. (forthcoming). Narrative of vicarious experience in broadcast news: a linguistic ethnographic approach to semiotic mediations in the newsroom. Special Issue on Vicarious narratives in talk at work.

Mishler, E. G. (1995). Models of narrative analysis: a typology. Journal of Narrative and Life History, 5(2), 87-123.

Montgomery, M. (2007). The Discourse of Broadcast News. A Linguistic Approach. London: Routledge.

Montgomery, M. (2005). Television news and narrative: how relevant are narrative models for explaining the coherence of television news? In J. Thornborrow \& J. Coates (Eds.), The sociolinguistics of narrative (pp. 239-260). Amsterdam: John Benjamins.

Mouillaud, M., \& Tétu, J.-F. (1989). Le journal quotidien. Lyon: Presses universitaires de Lyon.

News Text \& Talk Research Group (2011). Towards a linguistics of news production. Journal of Pragmatics, 43(7), 1843-1852.

Pekarek Doehler, S., De Stefani, E., \& Horlacher, A.-S. (2015). Time and emergence in grammar. Dislocation, topicalization and hanging topic in French talk-in-interaction. Amsterdam: John Benjamins.

Perrin, D. (2013). The linguistics of newswriting. Amsterdam, Netherlands: John Benjamins.

Perrin, D. (2011). “There are two different stories to tell." Collaborative text-picture production strategies of TV journalists. Journal of Pragmatics, 43(7), 1865-1875.

Perrin, D., Burger, M., Fürer, M., Gnach, A., Schanne, M., \&Wyss, V. (2008). Idée Suisse: Final report. Winterthur: Institute of Applied Media Studies.

Perrin, D., \& Wyss, V. (2016). In die Geschichten erzählen: Die Analyse von Narration in öffentlicher Kommunikation. In S. Averbeck-Lietz \& M. Meyen (Eds.), Handbuch nicht standardisierte Methoden der Kommunikationswissenschaft (pp. 241-255). Wiesbaden: Springer.

Rampton, B., Maybin, J., \& Roberts, C. (2015). Theory and method in linguistic ethnogra- phy. In J. Snell, S. Shaw \& F. Copland (Eds.), Linguistic Ethnography. Interdisciplinary Explorations (pp. 14-50). New York: Palgrave McMillan.

Revaz, F. (2009a). Introduction à la narratologie. Action et narration. Bruxelles: De Boeck.

Revaz, F. (2009b). L'éloquence du silence: analyse de la médiatisation du procès Swissair. In M. Burger, J. Jacquin \& R. Micheli (Eds), Les médias et le politique. Actes du colloque Le français parlé dans les médias. Lausanne: Centre de Linguistique et des Sciences du Langage. Retrieved from http:// www.unil.ch/clsl/page81503.htm.

Revaz, F., Pahud, S., \& Baroni, R. (2009). Une femme au gouvernement, un feuilleton électoral entre politique et people. Communication, 27(1), 139-158.

Revaz, F., Pahud, S., \& Baroni, R. (2008). Museler les toutous? Le feuilleton d'une polémique mordante. A contrario, 12(2), 2009, 46-65.

Revaz, F., \& Baroni, R. (2007), Le fait divers sérialisé, un feuilleton médiatique. Les Cahiers du Journalisme, 17, 194-209.

Revaz, F., Pahud, S., \& Baroni, R. (2007). Classer les « récits» médiatiques: entre narrations ponctuelles et narrations sérielles. In A. Chraïbi (Ed.), Classer les récits. Théories et pratiques (pp. 59-82). Paris: L'Harmattan.

Ricoeur, P. (1991). Life in quest of narrative. In D. Wood (Ed.), On Paul Ricoeur: Narrative and interpretation (pp. 20-33). London: Routledge.

Ricœur, P. (1985). Temps et récit. Le temps raconté. Paris: Seuil.

Ricœur, P. (1984). Temps et récit. La configuration dans le récit de fiction. Paris, France: Seuil.

Ricœur, P. (1983). Temps et récit. L'intrigue et le récit historique. Paris: Seuil.

Riegel, M., Pellat, J.-C., \& Rioul, R. (2014). Grammaire méthodique du français. Paris: Presses Universitaires de France.

Schegloff, E. A., \& Sacks, H. (1973). Opening up closings. Semiotica, 8(4), 289-327.

Schudson, M. (1982). The politics of narrative form: The emergence of news conventions in print and television. Daedalus, 111(4), 97-112.

Schütz, A. (1953). Common-sense and scientific interpretation of human action. Phi- 
losophy and Phenomenological Research, 14(1), 1-38.

Scollon, R. (1998). Mediated discourse as social interaction. A study of news discourse. London: Longman.

Stokoe, E., \& Edwards, D. (2006). Story formulations in talk-in-interaction. Narrative Inquiry, 16(1), 56-65.

Tannen, D. (2007). Talking voices: Repetition, dialogue, and imagery in conversational discourse. Cambridge: Cambridge University Press.

Tenenboim-Weinblatt, K. (2009). News as Narrative. In C. H. Sterling (Ed.), Encyclopedia of Journalism (pp. 953-956). Thousand Oaks: Sage.

Tétu, J.-F. (2000). La temporalité des récits d'information. Rennes: Apogée.

Tuchman, G. (1978). Making news: A study in the construction of reality. New York: Free Press.

Tuchman, G. (1976). Telling stories. Journal of Communication, 26(4), 93-97.

Tuchman, G. (1973). Making news by doing work: Routinizing the unexpected. American Journal of Sociology, 79(1), 110-131.

Ungerer, F. (2001). News stories and news events. A changing relationship. In F. Ungerer (Ed.), English media texts. Past and present (pp. 177-195). Amsterdam: John Benjamins.

Van Dijk, T. (1988a). News as discourse. Hillsdale: Erlbaum.

Van Dijk, T. (1988b). News analysis. Case studies of international and national news in the press. Hillsdale: Erlbaum.

Van Dijk, T. (1986). News schemata. In C. Cooper \& S. Greenbaum (Eds.), Studying writing: Linguistic approaches (pp. 155-186). Beverly Hills: Sage.

Van Dijk, T. (1985). Structures of news in the press. In T. Van Dijk (Ed.) Discourse and communication (pp. 69-93). Berlin: De Gruyter.

Van Dijk, T. (1983). Discourse analysis: Its development and application to the structures of news. Journal of Communication. $33(2), 20-43$.

Van Hout, T. (2015). Between text and social practice: balancing linguistics and ethnography in journalism studies. In J. Snell, S. Shaw \& F. Copland (Eds.), Linguistic eth- nography. Interdisciplinary Explorations (pp. 71-89). New York: Palgrave McMillan.

Van Hout, T., \& Jacobs, G. (2008). News production theory and practice: Fieldwork notes on power, interaction and agency. Pragmatics, 18(1), 59-85.

Vanoost, M. (2013). Defining narrative journalism through the concept of plot. Diegesis, 2(2), 77-97.

Zampa, M. (2017). Argumentation in the Newsroom. Amsterdam: John Benjamins. 